\title{
Storage Projects in Nepal's Electricity Development Decade 2016/2026 For Whom Nepal's Storage Projects Toll?
}

\section{Santa Bahadur Pun}

Abstract: The Nepal government's Electricity Development Decade 2016/2026 to develop 10,000 MW in 10 years has 11 storage projects totaling over $5,000 \mathrm{MW}$. Nine of these eleven projects would store 11 billion cubic meters of freshwater submerging vast tracts of fertile valleys, villages, farms and forests in Nepal. Brushing aside these social and environmental costs lightly, the government has launched the holy 'jihad/crusade' to develop hydroelectricity. Nepal's policy framers of $10,000 \mathrm{MW}$ in 10 years crusade have totally failed to see the larger picture in the Ganges basin. This failure to see the larger Ganges picture is, to a large extent, attributed to Prime Minister Madhav Kumar Nepal's 2009 decision to unbundle Water Resources Ministry into Energy and Irrigation. Electricity attained the upper class status with Water downgraded to Dalit class!

India's greatest burning problem in the Ganges basin, that supports nearly fifty per cent of her 1,200 million people, is WATER. India, therefore, is in desperate need of storages in Nepal to realize her master plan, the Interlinking of Rivers. With Nepal in desperate pursuit of hydroelectricity, India sees this as an opportune moment to avail GRATIS stored WATER through Nepal's default. According to Bhim Subba, a Bhutanese of Nepalese origin, this is the fundamental flaw in all past Indo-Nepal deals. Subba believes India must concede that success of her Ganges water strategy hinges entirely on Nepal. He argues that water stored in Nepal has monetary value and this must be factored in all storage projects. Such a policy would be mutually beneficial for both the countries. Unfortunately, this would be a bitter pill to swallow for our policy framers of 10,000 MW in 10 years crusade. This article dwells on these issues.

Keywords: Hydropower Project, Water, Electricity Development, Nepal

$\mathbf{N}^{2}$ epal's Electricity 2016/2026: The

Development Decade much-hyped Electricity Development Decade 2016/2026 was recently launched by Nepal's Energy Ministry to eradicate the decade-long national electricity crisis. One of the major thrusts of this crusade that envisages commissioning 9,935 MW of hydropower plants within the $2016 / 2026$ decade is on the 11 storage projects with an installed capacity of 5,373 MW. These storage projects are in addition to Nepal's 10,800 MW Karnali Chisapani Multipurpose Project ${ }^{1}$ of many decades ago now being readied to be 'reactivated' at an appropriate ${ }^{2}$ time. Already in Nepal's 'electricity development' net is the $3,300 \mathrm{MW}$ Saptakoshi High Dam that has strategically roped in the Sunkoshi-Kamala Storage-cum-Diversion scheme ${ }^{3}$. The 6,480 MW Pancheshwar Multipurpose Project, ratified by the Nepalese Parliament over two decades ago in 1996, is still stuck in deep quagmires with the unresolved ${ }^{4}$ issues of "sharing of project cost in proportion to accrued benefits, assessment of power benefit as compared with 'relevant' alternatives available, equal entitlement of Mahakali waters without prejudice to their existing consumptive uses, precludes the claim in any form the unutilized portion of the Mahakali waters etc. etc." ! Nepal's Electricity Development Crusade 2016 totally ignores Nepal's strategic position in the Ganges basin. India's thirst for freshwater will increase to formidable proportions by 2050 when her population is expected to stabilize at around 1,640 million ${ }^{5}$. Nepal studiously fails to read the writing on the wall: India's most burning problem is freshwater, the most precious resource. The root cause of this failure is Prime Minister Madhav Kumar Nepal's 2009 decision $^{6}$ to scissor-off the Water Resources Ministry into that of Energy and
Irrigation. Electricity became the thread-wearing upper class $^{7}$ whereas Water, unfortunately, got downgraded to the Dalit class!

WaterScarcityin Ganges Basin: The World Bank's 2012 Ganges Strategic Basin Assessment ${ }^{8}$ (GSBA), though a contentious document for Nepal, has a wealth of valuable information. The Ganges basin, as per the 2011 census, has a population of 656 million where 576 million Indians live (47 percent of India's population). Nepal's three bordering States of UP (199 million), Bihar (104 million) and West Bengal (91 million) have a staggering combined population of 385 million, far greater than that of USA. The Ganges basin has the world's highest population density and as a consequence poverty level borders that of sub-Sahara region. This is India's Hindu cow belt where water is increasingly getting scarce. The perennial unresolved inter-state dispute over the Cauvery waters in South India has spilled ${ }^{9}$ over to the Northern States. To tackle this dire thirst of the Ganges basin, India's National Water Development Agency (NWDA) prepared a National Water Master Plan with inter-basin water transfer - from the wet/ water rich basin in the east to the dry/water poor basin in the west - thus giving birth in 1987 to the Interlinking of Rivers (ILR).

India's Interlinking of Rivers (ILR): This Interlinking of Rivers has two major components, the Himalayan and Peninsular. The Himalayan component ${ }^{10}$, where Nepal's role is of vital importance, has 14 links with $6,099 \mathrm{~km}$ of canals, 9 big dams to provide $200 / 250$ billion cubic meters (BCM) of additional water for irrigation benefits to 22 million hectares of land and provide 1,120 cumecs of water for 
flushing the Kolkata Port besides generating 30,000 MW of hydropower. The Peninsular component has 16 links with $4,777 \mathrm{~km}$ of canals including 94 tunnels, 27 big dams to provide $84 \mathrm{BCM}$ of additional water to irrigate 13 million hectares and generate 4,000 MW of hydropower. On freshwater provisioning, the Himalayan component is three times larger than the Peninsular component. This is all due to Nepal which, despite having a mere $13 \%$ of the total Ganga basin catchment area, contributes $47 \%$ of the average annual flow of the Ganges. But during the critical dry months of February, March and April Nepal's contribution to the Ganges flow increases ${ }^{11}$ dramatically to as high as $75 \%$.

\section{Nepal in ILR's H i m a l a y a n C o m p o n e n t : Without storage projects in Nepal, India's River Linking Project will continue to remain in the National Water Master Plan's drawing boards. For among the 14 Himalayan Links, the following five} Nepal-related links are of extremely vital importance to India:

- Kosi-Mechi and Kosi-Ghagra (Karnali) Links: both links to be fed from 269 meter high Kosi High Dam at Barahchhetra, live storage 9.4 billion cubic meters $(\mathrm{BCM})$ of water and 3,300 MW of hydropower - Saptakosi High Dam already in the electricity producing net of Nepal Government.

- Gandak-Ganga Link: to be fed by 263 meter high Budhigandaki dam, live storage of $4.25 \mathrm{BCM}$ and 1,200 MW of hydropower - Budhigandaki Project ${ }^{12}$ already in Nepal's construction mode with $50 \%$ of the US\$ 1 Billion promised by Prime Minister Narendra Modi during his visit to Nepal in 2014.

- Ghagra (Karnali)-Yamuna Link: to be fed from 270 meter high Karnali Chisapani dam, live storage 16.2 BCM of water and 10,800 MW of hydropower; Karnali Chisapani Dam on the verge of being re-activated with Notices already floated to stop all construction works within the reservoir's submergence area.

- Sarada(Mahakali)-Yamuna Link: to be fed from 315 meter high Pancheshwar Dam, live storage 6.6 BCM of water and 6,480 MW of hydropower ${ }^{13}$; Pancheshwar multipurpose project ratified by the Nepalese Parliament in 1996 and the instruments of ratification already exchanged between the two governments in 1997.

These over 263 meter (868 feet) high four dams in
Nepal, sitting atop a seismically active zone, have a live storage of $36.5 \mathrm{BCM}$ of water. The famed 226 meter high Bhakra Nangal dam, that Nehru termed 'temple of resurgent India', has a live storage of 6.9 BCM.

\section{Nepal's Storage Projects in Electricity Development Crusade 2016/2026: To supplement the above mentioned massive storage projects, the Government of Nepal has now embarked on the following 11 storage $^{14}$ making crusade projecting even the estimated completion date:}


the diminishing Ganges flow ii) the financing institution World Bank, the honest broker, strongly recommending Nepal to ride on the wave of significant hydropower trade with simpler negotiations and iii) Nepal, the Storage Provider, straining at the leash to gleefully plunge into the crusade of developing 10,000 MW in ten years $-2016 / 2026$ !

Conclusion: Nepal has, since the 1965 Karnali Chisapani studies, consistently failed to see the larger picture on the wall - Nepal's strategic position as the water tank of the Ganges Basin.

i) Eugene Mihaly, the American researcher, noted as far back as 1965:

- large irrigation and flood-control projects on the Kosi and Gandak rivers - projects that India liked to describe as elements of its aid to Nepal;

- the almost unconscious view that Nepal was actually part of India, and that Nepal benefitted from Indian gains;

- the Indian inability to think of Nepal as a separate entity with the desire to go its own way; and

- no consideration appears to have been given to the fact that India was taking from a sovereign state the water on which its future depended!

ii) India in March 1990 presented to Nepal a Secret Agreement Draft ${ }^{18}$ on Mutual Cooperation wherein Article III on Water Resources Cooperation stated:

- The two Contracting Parties being equally desirous of attaining complete and satisfactory utilization of the waters of the commonly share rivers, undertake to (i) plan new uses or projects subject to the protection of the existing uses on the rivers and (ii) cooperate with each other to formulate and modify the planned new uses or projects taking into consideration the water requirements of the parties.

iii) Bhim Subba ${ }^{19}$, a Bhutanese engineer of Nepalese origin, penned in 2002:

- 71 per cent of the river's flow during the critical dry season comes from Nepali tributaries;

- success of an Indian water strategy to meet the growing water demand in Uttar Pradesh and Bihar, the country's most populous states..... hinges on Nepal;

- while a contributing factor for wariness among Nepalese stems from a widely held belief that Nepal has been 'cheated' by India on past water deals, the impasse can be directly traced to a fundamental flaw...... Nepal has been trying to sell electricity while it is water that India needs;

- short-sighted on the part of India to continue pursuing the current strategy which pins its hope on overcoming, by default, the impending water crisis through power projects;

- India should concede that regulating the Ganga waters is her primary concern; Nepal must.....redirect its efforts from trying to sell electricity to fulfilling this need for regulated water;

- Most importantly, ......stored water has monetary value and that this price must be attractive enough for Nepal to find it viable to design and build projects that optimize water storage instead of maximising power generation only!

India's mindset, as observed by Eugene Mihaly in 1965, has not changed at all - in fact, hardened more. India successfully enshrined the 1990 draft Agreement on Mutual Cooperation's 'subject to the protection of existing uses' in the 1996 Mahakali Treaty and scored further with the inclusion of 'precludes the claim, in any form, the unutilized portion of the Mahakali waters'. India would see to it that this precedent, set by the Mahakali Treaty, applies to all rivers emanating from Nepal into India.

The fundamental flaw Bhim Subba pointed out in 2002, Nepal desperately trying to sell electricity ${ }^{20}$ while India desperately trying to get free stored water through Nepal's default, continues to this day of $10,000 \mathrm{MW}$ in 10 years crusade. It is a fact that Nepal had been trying to sell electricity to India since 1965 from the Karnali Chisapani days of 1,800 MW size - now ballooned to $10,800 \mathrm{MW}$. It is again a fact that the 1954 Kosi and 1959 Gandak treaties ${ }^{21}$ were meant to avail water to India and the ratified 1996 Mahakali treaty further consolidated that. But the Bhutanese Bhim Subba argues that stored water has monetary value. He, therefore, believes that the price of this stored water must be attractive enough for Nepal to find it viable to design and build projects that optimize water storage ${ }^{22}$ instead of maximizing power generation. Such a policy would be "mutually beneficial" and thus create a win-win environment for both the countries.

For the Nepalese policy framers of 10,00o MW in 10 years crusade, the above analysis of a Bhutanese of Nepalese origin would be a bitter pill to swallow. This is because the Ministry of Water Resources was booted-off in 2009 by Prime Minister Madhav Kumar Nepal to create for his convenience the Ministries of Energy and Irrigation. The indoctrinated Ministry of Energy has been driving forcefully the agenda that water resources development merely means hydropower ${ }^{23}$ development. Besides the live storages of 32.2 BCM from Pancheshwar, Saptakosi and Karnali Chisapani, these policy framers are developing over 
5,00o MW of 11 storage projects to avail an additional $11 \mathrm{BCM}$ of regulated water GRATIS to India. While the famed Bhakra Nangal dam has a live storage of 6.9 BCM, India's controversial 263 meter high Tehri dam, showcased to all Nepalese VIPs visiting Delhi, has a mere live storage of 3.5 BCM! By forgoing the value of stored water and by forfeiting the huge social and environmental costs, Nepal is venturing into the storage building 'jihad/crusade' where even angels fear to tread!

S.B. Pun is Former Managing Director of Nepal Electricity Authority and in his closing years served as an Officer on Special Duty at Ministry of Water Resources, Government of Nepal. He writes on energy and water issues.

\section{Corresponding E-mail: santapun@ntc.net.np}

\section{Footnotes}

1. For the Karnali Chisapani project, under UNDP grant, 410 Nepalese engineers (250 for Karnali project and an additional 160 for Irrigation Department) graduated from India's premier Roorkee University. The first batch of 50 Nepalese students went to Roorkee in 1982.

2. See the undated Public Notice in the web site of Energy Ministry regarding Karnali Chisapani Multipurpose Project. The notice notifies all concerned not to carry out any construction activities in the reservoir submergence area below the elevation of $445 \mathrm{~m}$ mean sea level - affecting five districts and 41 VDCs. As the notice calls itself New in the web site, it was probably issued around November 2016, the date of the previous Notice.

3. The Kosi Basin Master Plan Study, conducted with JICA's assistance, recommended two top priority projects: Sunkosi-Kamala Diversion for irrigating 175,000 hectares in Dhanusha (108,000 ha) and Siraha (67,000 ha) and the 402 MW Arun III hydropower project. As usual, the Nepal government barked up the wrong hydropower tree. The SunkosiKamala diversion should have been undertaken by Nepal herself and not handed over to India.

4. As usual, it is likely that some of these key issues may have been already hammered out on a tete-a-tete basis and they would be spilled out to the public at a later appropriate date.

5. The Vital Links by Suresh Prabhu in Interlinking of Rivers in India: Issues and Concerns edited by MMQ Mirza, AU Ahmed and QK Ahmad, 2008, Taylor \& Francis Group, London. Suresh Prabhu, a Chartered Accountant by profession, was Union Minister for Power, Heavy Industries and Public Enterprises, Environment \& Forest and Industry at various times. From December 2002 to April 2004, he was Chairman of the Task Force on Interlinking of Rivers with the rank and status of Union Cabinet Minister.

6. This decision to bifurcate the Water Resources Ministry in 2009 was taken by Prime Minister MK Nepal in collusion with the Nepali Congress President, GP Koirala, to induct one more Nepali Congress stalwart into his cabinet - in essence to share the loaves and fishes of the poverty-ridden nation!

7. The Water Resources Ministry was headed by Dr. Prakash Saran Mahat with Shankar Prasad Koirala as the Secretary. After the 2009 bifurcation, both Dr. PS Mahat and SP Koirala opted for the Energy Ministry - thus clearly indicating which of the two Ministries had the upper status!

8. This GSBA is a World Bank South Asia Regional Report for Discussion of Regional Opportunities and Risks published in 2014.

9. The classic example is that of Haryana's upper caste anger over 'reservations' that led to the blowing up of the Munak canal in February 2016. This $102 \mathrm{~km}$ long canal from Jamuna supplies drinking water to onethird of Delhi's 17 million people. The army had to be called out to repair the sabotaged canal.

10. Impacts of Interlinking on Nepal by DN Dhungel \& SB Pun in Interlinking of Rivers in India: Issues and Concerns edited by MMQ Mirza, AU Ahmed and QK Ahmad, 2008, Taylor \& Francis Group, London.

11. Overview: Conflicts Over the Ganga? By SB Pun in Disputes Over the Ganga edited by Bhim Subba and Kishor Pradhan for Panos Institute South Asia. 2004. Kathmandu.

12. According to Dr. Laxmi Prasad Devkota, chairman of Project Development Committee, the project needs to acquire 58,000 ropanis (about 3,000 ha) of land in 27 VDCs of Gorkha and Dhading districts. The compensation amount ranges from Rs 524,000/to Rs 835,000/- per ropani (0.05 ha) - i.e over 40 billion Rupees. While 3,560 houses (@4.88 per household 17,372 persons) will be completely submerged, another 4,557 houses (22,238 persons) will be partially affected. Kathmandu Post, Money Janurary 4, 2017 (Poush 20, 2073)

13. Nepal, with the belief that peaking power has a high value in India, had the Pancheshwar DPR prepared for 6,480 MW. Media reports that India has downsized this capacity to 5,600 MW to optimize regulation of stored water.

14. Energy Ministry's National Electricity Crisis Eradication and Concept Paper and Work Plan on Electricity Development Decade, 2072. Singha Durbar, Kathmandu, Falgun 2072.

15. The live storage figures indicated in this chart were availed through the kind courtesy of Engineering Services, Nepal Electricity Authority. The writer regrets the live storages of Langtang and Khimti Those could not be availed.

16. This GSBA study was led by Claudia Sadoff and 
Nagaraja Rao Harshadeep of the World Bank.

17. Eugene Bramer Mihaly. Foreign Aid and Politics in Nepal - A Case Study. 1965. Royal Institute of International Affairs. Oxford University Press. London. Mihaly came to Nepal in 1961 for his PhD thesis from the London School of Economics. He has served in the faculty of the Haas School of Business at the University of California at Berkeley. Since 1996, he has been Adjunct Professor at the Tuck School of Business at Dartmouth - courtesy Himal Books, Lalitpur, Nepal.

18. Avtar Singh Bhasin. Nepal's Relation with India and China - Documents 1947-1992. 1994. SIBA EXIM Pvt Ltd. Delhi. This draft was delivered by SK Singh, India's then Foreign Secretary, to King Birendra's Panchayat regime in March 1990 at the height of India's 15 months' Trade and Transit embargo. It is reported that King Birendra, finding that this Draft Agreement was far harsher than the 1950 Treaty of Peace and Friendship, decided to bow to the wishes of his people rather than India. Prime Minister Marichman Singh is reported to have publicly stated if that Draft Agreement had been signed, then the Panchayat regime would have continued for another $15 / 20$ years!

19. Bhim Subba in Water, Nepal and India in Kanak Mani Dixit and Shastri Ramachandaran edited book State of Nepal. 2002. Himal Books. Lalitpur Nepal. Bhim Subba, Bhutan's first electrical engineer, worked for the Royal Government of Bhutan from 1975 onwards. He headed the kingdom's power department between 1986 and 1991 - courtesy Himal Books, Lalitpur, Nepal. Bhim Subba then landed up in Nepal as one of the 125,000 Bhutanese refugees. He has authored Himalayan Waters, 2001, published by the Panos Institute South Asia, Kathmandu. Like all Bhutanese refugees, he has migrated abroad. This speaks volumes about the shameful state of affairs of the 28 million strong nation being bullied by a nation of 600,000 - a 1991 population census claimed by the Bhutan government! With over 100,000 Bhutanese kindly resettled in their countries by the governments of USA, Canada, UK, Australia etc., Bhutan still continues to bully Nepal by refusing to take back her remaining 12,00o citizens, languishing at the Jhapa refugee camps! And New Republic Nepal still continues to suffer no bad conscience at the plight of these Bhutanese she gave refuge to since 1991 - totally preoccupied tinkering with the New Constitution after having overwhelmingly rejected the "best but outdated" 1991 Constitution!

20.There are reports that India's December 5, 2016 Guidelines on Cross Border Trade of Electricity and the Indo-Nepal PTA Agreement of October 21, 2014 on Electric Power Trade, Cross-Border Transmission, Interconnection and Grid Connectivity are contradictory. This discussion is beyond the scope of this article. One merely needs to assess the past history of Indo-Nepal power trading - the intent and the spirit or rather the lack of it!

21. While the 1996 Mahakali treaty recognizes '.. without prejudice to their respective existing consumptive uses of the waters of the Mahakali ..., this is not the case with the 1966 revised Kosi treaty that stipulates 'the Union shall have the right to regulate all the balance of supplies in the Kosi river at the barrage site thus available... $\therefore$ And the 1964 amended Gandak treaty requires India's consent for 'trans-valley uses of Gandak waters .....in the months of February to April only'. Both the Kosi and Gandak treaties do not recognize India's 'prior use right!'

22. India has applied this principle of maximizing storage to regulate stored water for irrigation on the 3,300 MW Saptakosi multipurpose projects. For the same precise reason, it is reported that Pancheshwar's $6,480 \mathrm{MW}$ of hydropower has been down-sized to 5,600 MW!

23. Under the USAID financed SARI/EI program, the Delhi-based Integrated Research and Action for Development (IRADe) launched the report "MacroEconomic Benefits of Nepal-India Electricity Trade" at Hotel Radisson Kathmandu on January 19, 2017. The Nepalese media, Kathmandu Post/ Money Jan. 20, 2017, headlined "Nepal can Earn Rs 1 Trillion a Year by Selling Power". According to the IRADe report, Nepal, by selling India 13,000 MW in 2030 and 34,00o MW in 2045, can earn annually revenues of Rs 310 Billion and Rs 1,069 Billion respectively. While ratifying the Mahakali Treaty in 1996, the then Water Resources Minister, Pashupati SJB Rana, promised in the Parliament that Nepal would earn Rs 24 Billion annually through sale of her portion of electricity from the 6,480 MW Pancheshwar project. The ebullient Minister Rana, in fact, claimed that Nepal's sun will, henceforth, rise from the west. Twenty one years later, Nepal's sun still continues to rise from the east. Recently on December 5, 2016, the Government of India "in order to promote transparency" issued the Guidelines on Cross Border Trade of Electricity stressing that cross border electricity trade involved "issues of strategic, national and economic importance". For cross border electricity trade with India from hydropower projects in Nepal, the guidelines provisioned preferential treatment for the entities (generation projects, power trading companies) that have majority equity investment of Indian public and private sector. Thus, India has finally become "transparent" on why the 10,800 MW Karnali Chisapani multipurpose project failed to materialize and why, like in Bhutan, she is clearly sending the message to third party foreign investors to be wary about investing in Nepal's hydropower projects that eye Indian market 